\title{
A Study of the Regional Financial Industry Layout and Local Economic Development
}

\author{
Fangliang Huang ${ }^{1}$, Jinhui Guo ${ }^{1}$, Junjun $\mathrm{Shi}^{1} \&$ Yunxiao $\mathrm{Ma}^{1}$ \\ ${ }^{1}$ School of Finance, Shandong University of Finance and Economics, China \& Capital Management Research \\ Institute, Shandong Financial Industry Optimization and Regional Development Management Research Center, \\ China \\ Correspondence: Fangliang Huang, School of Finance, Shandong University of Economics and Finance, \\ Shungeng Road 40, Jinan, Shandong Province, China. Tel: 86-531-82911084. E-mail: finance2016@sina.cn
}

Received: January 26, 2015 Accepted: March 2, 2015 Online Published: May 31, 2015

doi:10.5539/jms.v5n2p108 URL: http://dx.doi.org/10.5539/jms.v5n2p108

\begin{abstract}
The development of a nation's financial industry has been playing an important role in promoting the economic growth. The regional financial industry layout is an important factor affecting the local economic development. Therefore, it is significant to examine how the regional financial industry is organized. The financial structure optimization theory forms the basis for the study of the regional financial industry layout. Perspectives of the financial structure rationalization and sophistication can be adopted to examine the optimization of regional financial industry layout. The theory of industrial agglomeration, industrial cluster, and financial geography also contribute to the analysis of the financial industry layout and economic development. Financial industry cluster is the result of the financial industry's constant aggregating. The clustering effect can stimulate the development of the financial industry, and thereby to optimize the regional financial industry layout. The regional financial industry layout's effect on the local economic growth process can be analyzed through the observation of the process of the capital formation, the technological progress and the industrial structure.
\end{abstract}

Keywords: financial structure, industrial agglomeration, local economic development, regional financial industry layout

\section{Introduction}

The relationship between financial development and economic growth, which may affect the development of a national monetary policy and the development of the economy, is one key research focus in the economic area. From the relevant researches in the field of financial development and economic growth, it can be seen that there is a mutually reinforcing relationship between financial development and economic growth. The role of financial development on economic growth is not to be ignored either to a country or to a local area.

The layout of the regional financial industry is an important factor affecting local economic development. It is a very worthwhile to study how to optimize regional financial industry layout based on the characteristics of the local economy so that it can be more conducive to local economic development.

The financial industry layout is closely related to the financial structure. The financial structure optimization theory is the basis for the study of the regional financial industry layout. So firstly this paper studies the financial structure optimization theory, pointing out the paths of financial structure optimization. Then it analyses the theory of industrial agglomeration and industrial cluster effect. The financial industry agglomeration is of significance to the financial industry layout. The financial industry cluster is usually the result of the financial industry agglomeration. In the regional financial industry layout, consideration should be paid to promote the formation of financial industry clusters, to take advantage of external economies of scale, acquiring and processing related information more efficient, so that the regional financial industry can achieve better development and promote the local economic growth. The formation of regional financial center through the agglomeration effect can promote the development of the financial industry. In the perspective of the study of financial geography, this paper analyzes the geographic differences among the financial elements of the movement and its influence on the regional financial industry layout. Finally from the areas of capital formation, technological progress and industrial structure, we illustrate role of the financial industry layout in the local economic growth process. 


\section{Literature Review}

\subsection{Review of the Researches on the Financial Development and Economic Growth}

In the study of the relationship between financial development and economic growth, many of the results have indicated a positive correlation between them both from theoretical and empirical aspects. Financial intermediaries play an important role in promoting economic growth (Greenwood \& Jovanovic, 1990; Bencivenga \& Smith, 1991). The neoclassical growth model by embedding information validation framework to explore the relationship between financial development and economic growth, found the technological innovation in the financial sector and capital accumulation is more conducive to promote economic growth (Greenwood, Sanchez, \& Wang, 2010). These theoretical studies show that the financial development has a promoting effect on the economic growth, that the financial markets and financial institutions play a key role in economic development. Empirical studies have focused on the following areas. A highly capitalized and highly liquid stock market can effectively promote economic growth (Christopoulos \& Rousseau, 2002). Financial development and economic growth have long-term positive effects, but no short-term effects. So the formulation of financial policy should focus more on the long-term effects (Tsionas, 2004). Bank credit and stock market development and financial deepening can significantly promote economic growth. In developing countries, the promotion of financial development on economic growth more significantly, financial supporting policies are more effective (Apergis \& Filippidis, 2007). In the less developed European countries, financial development have a more significant impact on economic growth, and the contribution of financial integration on financial development is more significant (Arjana \& Masten, 2008).

There appeared a two-way causal relationship between financial development and economic growth in China, but there is not a causal relationship between investment and economic growth. Further sub-regional studies show that the eastern regions' financial development has promoted the local economic growths, while the central and western regions' financial development and economic growth were negatively correlated (Ai, 2004). Financial growth can effectively promote local economic growth, but the underlying causes can only be economic growth, the china exist demand follow relationship between financial development and economic growth (Wu, 2010).

Because China is a vast country, and local economic development is of great imbalance, scholars believe that further study should be conducted to examine the relationship between regional financial development and local economic growths. Some scholars used the data from1995 to 2005 in Shandong Province, the research results showed that there are positive correlation between financial development and economic growth only in Tai'an, other areas were not significant or of negative correlation. Different regions of the same province were not inconsistent in the relationship between the financial development and the economic growths (Cao \& Wang, 2006). With the financial interrelation ratio and loan balance of financial institutions as a measure of the level of financial development index, research on the relationship between financial development and economic growth show that there was a significant positive correlation between them in 11 cities in Zhejiang province (Qian \& Sun, 2008). According to the data of Gansu Province during 1978-2010, in the long term to expand the scale of Gansu finance development significantly contributed to economic growth, but the efficiency of financial intermediation declined with the economic growth (Guo, 2013). And according to 1952-2011 years of time-series data, financial development in Shandong Province was not a good play role in promoting economic growth, but economic growth had a positive impact on financial development (Wang, 2013).

In recent years, with the importance of the three major economic zones increasing in China's economic development, there was an increasing trend of researches on the relationship between financial development and economic growth in three major economic zones. Most studies found that financial development of the three economic zones promote local economic growth. In the Yangtze River Delta economic zone, financial development could promote economic growth, but there was a certain lag, this promotion was not only reflected in the stock, but also reflected in the increment that the region's financial efficiency to improve (Ye \& Wang, 2007). In the Bohai Economic Zone, the total financial assets increasing and the improving of the efficiency of financial intermediation played the maximum role in promoting economic growth, and there were significant differences in the development of provincial and municipal financial impact on economic growth, including Hebei financial development had the minimum impact on economic growth (Wang \& Cui, 2010). In the Pearl River Delta between financial development and economic growth were mutually reinforcing, excessive behavior of the government was likely to damage the financial and economic role in promoting mutually (Huang, 2012). Based on the data of Yangtze River Delta region, the empirical econometric analysis results indicated that the development of financial intermediation promoted the improvement of local economic growth, the development of the financial intermediaries could affect industry growth, especially in the second industry growth (Zhi, 2013). 
From the relevant researches of financial development and economic growth, we found that although related research can continue to make progress in the past few decades, many scholars believe that the existence of a mutually reinforcing relationship between financial development and economic growth, but the extent of this impact and the role of the path remain to be discussed. The relationship between financial development and economic growth also needs to be analyzed. Issues about what type of financial system are more conducive to economic growth and the impact of financial policies on economic growth are to be explored.

\subsection{Review of the Researches on the Regional Financial Industry Layout}

Optimizing industrial development layout is an important guarantee for the sustainable development of the region. It is a matter of current and long-term strategic development work. Scientific planning the layout of the financial industry, both financial institutions to reduce costs, diversify risk, process reengineering, integration of resources internal needs, and the external power of enhancing the core competitiveness and overall business performance. Under the economic globalization and the international financial crisis, this is more of an inevitable choice for the further development of the financial sector.

Taking into account the differences of economic and financial development between regions, here we only sort out the financial industry layout of China's regions. Research from the large areas to the municipal level and then to the municipal following ranges are involved. The administrative factors are the main factors that determine the layout of financial institutions. The non-economic distribution of financial institutions is more prominent (Zhou, 2004).

There are also some researches on the layout of the financial industry in Shanghai, China's economic and financial center. Shanghai's booming financial industry cannot hide its structural imbalance, the core financial industry ahead of the development, and the auxiliary financial industry and the support financial industry is relatively backward. Shanghai's financial industry restructuring directions should include two aspects. First, the balance of Shanghai's financial industrial structure should be maintained at a higher level. Second, it is to develop the specialization of institutions specialized in financial ecological environmental improvement $(\mathrm{Fu}$, 2010). The construction of Shanghai, Beijing, Guangzhou and Shenzhen and other financial centers must be based on local conditions, highlighting its own characteristics and advantages, to avoid similar functions, redundant construction and blind competition (Zhang, 2011). Traditional theory holds that financial agglomeration has a very important role in the development of financial center. It is the microscopic foundation for the formation of financial center. Development of London, New York and other international financial centers indicates that financial diffusion is an inevitable phenomenon that financial cluster development to a certain stage.

The banking industry as the main body of the modern financial industry is the hub of the national economy. For the study of the regional banking layout is very meaningful. Through the empirical analysis of the institutional layout of city commercial banks in china found that the website setting is unreasonable, it is difficult to form the conclusion of economies of scale (Li \& Zhang, 2001; Sun, 2006). Using spatial analysis in AicGIS software and from the financial geography point of view to study the rural banks network layout problems in Songzi, we have come to the conclusion that spatial layout of bank branches in rural areas is extremely imbalanced, and proposed suggestions mainly for the spatial layout of the Agricultural Bank, rural credit cooperatives and postal savings bank (Xiao, 2011).

The layout of regional financial industry is a very worthwhile study. However, researches in this area are still not enough, which is exactly what we need to further study.

\subsection{Review of the Researches on Financial Industry Layout and Economic Development of the Blue Economic Zone in China}

As to the study of the financial industry in Blue Economic Zone China, mostly concentrated in analyzing the current development of Blue Economic Zone and combined with the relevant regional development experience of foreign blue economy, and proposed the financial support strategic policy and path for the construction of the Shandong Peninsula Blue Economic Zone.

The financial industry should be the organic composition of the Shandong Peninsula Blue Economic Zone in China. The specific measures of financial support to the construction of the Shandong Peninsula Blue Economic Zone including constructing multi-level financial market system, multiple channels to raise funds, banks should actively carry out financial innovation, strengthening the support of credit funds; the introduction of policy insurance mechanism, and provide strong protection for financing of Peninsula Blue economic Zone (Wang \& Feng, 2010). Regarding the issue of the path Selection on the financial support Peninsula Blue Economic Zone, 
we should co-ordinate planning the coordinated development of regional financial and broaden the financing channels of Peninsula Blue Economic Zone, Improve the utilization efficiency of regional financial resources through the integration of financing costs, and optimize the financial environment (Jia \& Wang, 2012). Banking industry development is uneven, city commercial banks development is lagging behind in Shandong Peninsula Blue Economic Zone, we should create a professional "blue bank" (Lin \& Yan, 2011). Qingdao should play the role of the core city, optimizing the funds in specific investment and cultivate a listed company, and the full use of capital market financing policy to improve financial support for economic growth (Han, 2012). Through financial innovation support the development of marine economy (Development and Reform Commission of Academy of Macroeconomic Research Group in Shandong Province, 2012).

The Research for Blue Economic Zone of the financial industry remains inadequate. By studying the development status of the Shandong Peninsula Blue Economic Zone financial industry, Zhang(2013) found that the distribution of financial institutions is extremely uneven and there are large differences in the level of development.

From the study of the entire national and regional perspective, we found the mutual promotion relationship between financial development and economic growth. Regional financial industry layout is an important factor affecting regional financial development. So it is very important for the study of regional financial industry layout. At present, the study of regional financial industry layout is also very small, and specifically for the study of the layout of the financial industry in Shandong Peninsula Blue Economic Zone is less, which is what we need to focus in our researches.

\section{A Theoretical Study of Regional Financial Industry Layout}

\subsection{A Theoretical Analysis of Regional Financial Structure Optimization}

Theoretically speaking, the financial industry is closely related to the financial structure layout. Researches on financial structure optimization theory form the basis of regional financial industry layout.

\subsubsection{Analysis of the Stage of Development in Financial Structure}

To analyze the connotation and types of financial structure is our logical starting point for the study of financial structure optimization.

1) The connotation of financial structure

The American economist, Raymond W. Goldsmith, first proposed the definition of financial structure in his book The Financial Structure and Financial Development. Financial structure is the relative scale of financial instruments and financial institutions. A country's financial structure characteristics are constituted of the form, the nature and the relative scale of various financial instruments and financial institutions.

According to the research results of different scholars, we can make the following definition of the financial structure: Financial structure is the exists of components of the financial system, the relative size and the state and results of the interaction of the structure of the financial industry, financial market structure, financial instruments structure, the financial price structure and other components.

Financial structure is the basic organizational framework of financial activities. It has many aspects of connotation and has the characteristics of integrity, complexity, hierarchy and dynamic nature.

Different financial structures have different effects on the economy. It is of great significance to discover the role of finance in the economy through the research on financial structure. Goldsmith's study in 1955 laid the foundation for studies of financial structure. This paper is The Financial Structure and Economic Growth in Developed Countries - the experiment of comparison way about financial form. Gurley and Shaw co-published the book about monetary capital in the financial theories in 1960. It pointed out that there are two different types of financial intermediaries. One is banking institutions, and the other is non-bank financial intermediaries. On this basis, it summarized the differences by comparing the two types of institutions. Goldsmith pointed out that financial instruments and financial institutions determine the financial structure in the book Financial Structure and Financial Development. Goldsmith's most important contribution to the study of the financial structure is to design a set of index system to examine the state of financial structure. He also analyzed the financial structure evolution path through collecting data in a number of countries. After Goldsmith, in 1990s, endogenous financial economy growth theory developed and became the most influential theory of financial structure. The theory is based on the discussion of endogenous mechanisms in financial markets and bank intermediation. The financial structure is divided into bank (intermediation) oriented modes and financial market oriented modes. And it analyzed the advantages and disadvantages of the two modes. The above are early studies on the financial 
structure. Now a hot study for the financial structure is the financial structure optimization.

Financial structure optimization is a more complex financial issue. Not only did it involve the structure changes and adjustments between the various elements of the financial industry, but also involve the relationship between changes in the economic structure. Meanwhile it closely related to the economic and financial development strategy and institutional model. Regional financial structure optimization analyses the issue of the financial structure deeply. The analysis for the financial structure optimization needs to build a complete theoretical framework. It provides the theoretical foundation for the study of specific problems of financial structure.

\section{2) Types of financial structure}

Financial structure is divided into three basic types by Goldsmith according to financial related ratios and other indicators: the initial phase of the financial structure development, the development stage of the financial structure development and the mature stage of the financial structure development.

Financial interrelation ratio is relatively low in the initial stage of financial structure and is from 0.2 to 0.5 . Financial instruments are relatively single. Debt certificates are much higher than the equity certificates. The status of commercial bank is more prominent in the financial institutions. Financial interrelation ratio is still low in the development stage of financial structure. The debt assets continue to occupy the vast majority of the total financial assets, and commercial banks still play a leading role in financial institutions. But at this stage the government and government-led financial institutions play a greater role than ever before in the economy running, and the proportion of financial intermediation is relatively high. The financial interrelation ratio is highest among the three stages in the mature stage of the financial structure development, which is about 1 or so, sometimes up to 2 . The equity assets accounted for an increase in the proportion of total financial assets. The diversification trend of financial institutions strengthened, and commercial banks are still in the dominant position. But the market position of the securities, insurance and other non-bank financial institutions increased.

The development of a country's financial structure is a process from one type to another type. Moreover, different countries have different economic environment, which may appear the state of financial structures between these three types.

\subsubsection{The Paths of Financial Structure Optimization}

Financial structure optimization is a relative concept. There is no universal optimal financial structure. Financial structure optimization does not refer to the financial structure to reach an optimal state, and it is an approaching process to this optimal state. And it is an optimal state that the financial structure achieved a balanced of supply and demand.

Financial structure optimization has two basic points: financial structure rationalization and financial structure sophistication.

Financial structure must first achieve the rationalization in order to achieve the sophistication. Rationalization of the financial structure is the basis of the financial structure to achieve sophistication. And the relationship is interaction and mutual penetration.

Within a certain time frame, there is a state of optimal financial structure that the financial structure rationalization and sophistication coordinate each other. At this point, the rationalization of the financial structure and financial structure sophistication interacted. Financial structure optimization has become an ongoing dynamic process of approaching the Pareto optimization. The relationship of the rationalization of the financial structure, financial structure sophistication and the target of financial structure optimization can be obtained from Figure 1. 


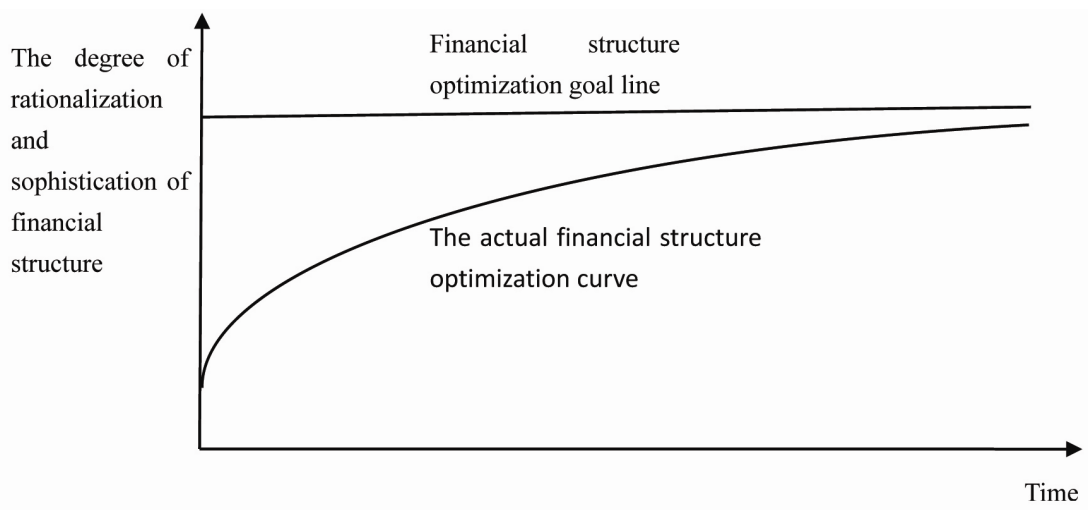

Figure 1. Financial structure optimization path

In Figure 1, the horizontal line indicates the financial structure reached Pareto optimal state. With the passage of time, the actual financial structure optimization curve continuous close to the goal line of financial structure. Over time, there will be a new financial structure optimization goal line with the changes in economic and financial environment. The actual financial structure optimization curve will approach toward the goal line.

In the process of optimizing the financial structure, we should combine the financial structure rationalization and financial structure sophistication organically. Financial structure rationalization promotes the financial structure sophistication and the financial structure sophistication led to the financial structure rationalization.

At different times, financial structure optimization should focus on the actual situation of the financial structure. Financial structure optimization model can be summarized as shown in Figure 2.

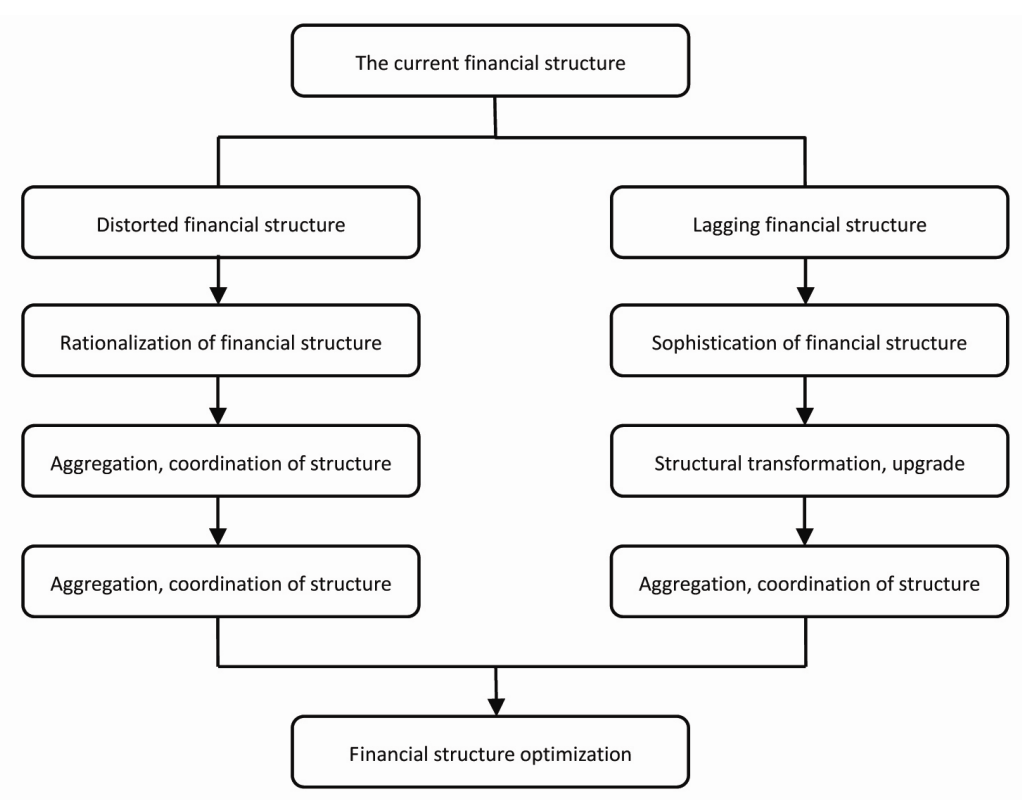

Figure 2. Financial structure optimization model

Regional financial industry layout refers to the relevant theories of financial structure optimization. We can examine the optimization of regional financial industry layout from the perspective of the rationalization and sophistication. When the financial industry is irrational, the optimization of the financial industry layout should focus on the rationalization. We should adjust the spatial layout of financial institutions to optimize the financial industry layout. When the financial industry is lack of sophistication, the financial industry supply lags behind the overall financial demand. Financial industry layout should be focused on financial industry sophistication. We should promote the innovative development of financial industry and optimize the financial services to make 
the financial industry function meet the economic development demand.

\subsection{A Theoretical Analysis of Industrial Agglomeration and Regional Financial Industry Cluster}

With the continuous development of the financial industry as well as the development of financial geography, the financial industrial agglomeration has become a new research focus. And it is of great significance for the financial industry layout.

\subsubsection{The Industrial Agglomeration Theory}

Industrial agglomeration can be defined as a group of related companies and organizations in the geographical proximity. Due to the commonality and complementarities, they linked and formed a strong and sustained competitive advantage. And they are in the same industries or related to particular industries (Porter, 1990). Industrial agglomeration can be understood as the homogenization of enterprises concentrated in a particular area to provide a certain type of products or services. The enterprise aggregation with a competitive advantage formed by stabilizing the division of labor and complex network relationships and it is a geopolitical phenomenon. Industrial agglomeration reveals the phenomena and mechanisms that the related businesses and supporting institutions in some places gathered in groups to gain competitive advantage.

\subsubsection{The Financial Industry Cluster Theory}

Financial industry cluster is the result of the financial industry's constant aggregating. What should be considered include the promoting of the formation of the financial industrial clusters and taking advantage of external economies of scale to get and process the relevant information efficiently. Finally the regional financial industry will gets better development and promotes the local economic growth.

Financial industry cluster is the financial companies and related social service agencies through market and non-market contacted in a specific area. By the mutual competing, mutual cooperation and geographically highly concentrated formed the industrial organizations. The industrial organizations have a cluster feature and play an important role in the local economic development. Financial industry cluster has the following features: spatial aggregation, network nature, product complex nature, embeddedness and openness (Qin, 2009).

\subsubsection{The Financial Industry Agglomeration Motivation}

1) The financial industry's characteristics

The embeddedness, high-growth and high liquidity of the financial industry are the motivation of financial industry agglomeration. Financial industry often localized, its producing activities will penetrate into the economic, social, cultural and political relations of the region. The embeddedness of the financial industry will promote financial industry gathering. On the one hand, the financial industry's high growth promotes the new financial institutions derive from intra-regional. On the other hand, it attracts the external financial institutions to enter the area so that the scale of financial industry agglomeration continues to expand. The high liquidity of the financial industry can accelerate the financial industry agglomeration. When the financial industry developed to the intermediate stage and the advanced stage, the financial industry agglomeration can even surpass the industry agglomeration process.

\section{2) External economies of scale}

External economies of scale are a large number of industrial enterprises concentrated in a small country or a particular region in one country. External economies of scale can improve efficiency, reduce costs and increase revenue. External economies of scale have a direct role in the financial industry, thus contributing to the development of the financial industry agglomeration. And External economies of scale also act on other industries, the other industries development has the opposite effect on the financial industry and deepens financial industry agglomeration. With the deepening of the financial industry agglomeration, the external economies of scale will gradually expand.

\section{3) Particularity of financial information}

Financial information is the available information in the financial activities including the main financial information, financial activities information and financial product or service information. Financial geography theories considered that the financial industry is largely depend on the information in order to provide high value-added and professional intermediaries services. Financial institutions should not only receive and use information, but also turn the low-level information into the high-level information. The nature and flow of the information affect the development of the financial industry. Externalities of financial information and asymmetric information promoting the formation of the financial industry cluster. 


\subsubsection{A Theoretical Analysis of the Financial Industry Agglomeration and Regional Financial Center}

Financial industrial agglomerations are through coordination, configuration and the changes of combination between the financial resources and geographical conditions to promote the growth of the financial industry. Thus it will generate the financial regional intensive system in certain geographical space. It is an evolutionary process from the financial agglomeration to the financial center. Financial center is the result of the financial industrial agglomeration, and it is the performance of the financial industry cluster.

There are mutually reinforcing relationship between financial agglomeration and financial center. On the one hand, when the regional financial industrial agglomeration developed to a certain extent, many financial institutions and the service agencies related to financial industry gradually aggregated. Various financial factors such as capital and talents also gathered and financial instruments innovated and developed. Finally the region formed a sound financial system and perfect financial markets, and the region will become a financial center. When the degree of financial agglomeration deepening, regional financial center will developed into a national financial centers and even an international financial center. On the other hand, the formation and development of the financial center will attract a variety of financial resources and financial institutions to aggregate and accelerate regional financial industrial agglomeration.

During the regional financial industry layout, we should consider promoting the financial industrial agglomeration, forming a regional financial center and promoting the development of the financial industry through clustering effect.

\section{The Study of Layout of Regional Financial Industry from the Perspective of Financial Geography}

The layout of regional financial industry means the space distribution and geographical combination of cash and cash equivalents, financial instruments, financial institutions, financial market, financial system and other financial factors. However, financial geography treats the difference of time and space in the financial industry as research objects and it is the combination of microcosmic views and macroscopic views. According to the financial geography point of view, the process of formation and influence of regional financial industry layout are as follows.

1) Distribution pattern of social wealth, local economic operating level, adjustments of local economic structure and improvements of local economy generate different regional market interest rates ultimately. Finally, cash and cash equivalents based on the signals guidance of market interest rates to invest in unique regions to realize the maximum utilization efficiency.

2) The regional economy has obvious geographical characteristics in the aspect of popularization and innovation of financial instruments, financial habits and preferences, market interest rates and inflation expectations and other factors. So there are significant differences in the supply and demand contents of financial institutions. The supply and demand of financial instruments makes feedbacks and adjustments throughout price signals. Finally this will make the overall market supply and demand balance.

3) The national income distribution pattern, financial habits and quality of financial professionals leading to economies of scale. The management technology level enables the market development of financial institutions and regional integration.

4) The location of financial markets is the result of a direct effect of geographic factors. The regional structure of the financial markets eventually led to the formation of the spatial pattern of financial transactions. And the location maps become more complex and fragmented.

5) Because the regional differences in the overall function of finance, there exist financial system and regulations learning, imitation and regional integration.

\section{The Role of the Regional Financial Industry Layout in Promoting Local Economic Development}

\subsection{The Role of the Regional Financial Industry Layout in Promoting Capital Formation}

\subsubsection{Improvement of the Conversion Ratio of Savings to Investment}

Reasonable regional financial industry layout makes the financial institutions and financial markets gathered, and indirect financing system and direct financing system cooperated. On the one hand, banks and other financial institutions put the idle funds of the markets together in the form of savings through effective financial instruments and financial system. So the capital are allocated to the efficient productive sectors to avoid the high information cost and the weak risk control ability of the individual market participants, and to increase the channels of savings into investment. On the other hand, the direct financing can reduce information asymmetry of financial transactions, the moral hazard and adverse selection relying on the strict financial regulatory system 
and the information disclosure system in the reasonable regional financial industry layout. And this will optimize the allocation of resources. Therefore, a reasonable construction of the regional financial industry layout can improve the conversion ratio of savings to investment. So the total amount of capital will increase, which is good for local economic development in the case of other conditions unchanged, and the economic development will have a more solid material foundation.

\subsubsection{Improvement of the Capital Utilization Rate}

Rational regional financial industry layout makes the financial markets gathered. The way and direction of capital using have a variety of options. The objective of profit maximization of investment will allow capital to invest in higher yielding projects in finance market. And the lower yielding projects will be unable to obtain the appropriate financial support, and then the low levels and the low outputs industry will be gradually phased out. Therefore, the rational regional financial industry layout will improve the capital utilization rate and lead to higher levels of output and increase social wealth in the total amount of capital unchanged relatively. And thus this will accelerate the local economic development.

\subsection{The Role of the Regional Financial Industry Layout in Promoting Technological Progress}

Technological progress includes technological innovation and technological applications. They all need financial support. This is inextricably linked with the rational regional financial industry layout. Technological innovation carries high risks. The technological innovation can be carried out strictly before the event of risk regulation, during the event of risk regulation and after the event of risk regulation by the effective financial system exists in the reasonable regional financial industry layout. And this will reduce the adverse selection and moral hazard behavior and increase the success probability of technological innovation. The technological applications also exists risk. Application of new technologies generally requires a longer period to bring investment returns for investors, and the longer the period the greater the uncertainty. Rational regional financial industry layout can make the capital gathered and overflowed effectively, and the strict financial institutional arrangements can disperse the appropriate financial investment risk. These all contribute to the application of new technology, and thus the technological progress will promote the economic development.

\subsection{The Role of the Regional Financial Industry Layout in Promoting the Optimization and Upgrading of the Industrial Structure}

The adjustment, optimization and upgrading of industrial structure are inseparable from financial support. The flow of financial resources makes the financial resources shift from the alternative industrial sector into new industries and promotes the optimization and adjustment of industrial structure. Therefore, a reasonable regional financial industry layout not only provides the necessary financial support for the upgrading of industrial structure, but also can form a flexible and effective financing mechanism and bring the improvement of financing efficiency. So it will ease the insufficient financial resources in the process of coordinated development of three industries.

\section{Conclusion}

This paper focuses on the theoretical examination of the regional financial industry layout and local economic development. The situation of the regional financial industry layout can be explained by the relevant theories of financial structure optimization. Perspectives of the rationalization and sophistication can be adopted to examine the optimization of regional financial industry layout. The promotion of the financial industrial agglomeration can lead to form a local financial center and to stimulate the development of the financial industry through the clustering effect, and thereby to optimize the regional financial industry layout.

Through the study of the regional financial industry layout and local economic development, we found that regional financial industry layout can play an important role in promoting local economic development. An optimized structure of the regional financial industry is helpful to the promotion of the capital formation, the technological progress and the optimization and upgrading of the local industrial structure.

\section{Acknowledgments}

We gratefully acknowledge the financial support of the National Social Science Fund of China (11BJY139), The Key Research Project of Shandong Peninsula Blue Economic Zone, and The Yellow River High Efficiency Ecological Economy, and Shandong Social Science Key Commissioned Project of Financial Industry Optimization And Regional Development Management (14AWTJ01-5).

\section{References}

Apergis, N., Filippidis, L., \& Economidou, C. (2007). Financial Deepening and Economic Growth Linkages: A 
Panel Data Analysis. Review of World Economics, 143(1), 179-198. http://dx.doi.org/10.1007/S10290-007-0102-3

Ai, H. D., Xu, M. S., \& Guo, K. (2004). Empirical Analysis of Regional Financial Development and Local economic Growth in china. Research on Financial and Economic Issues, 26-32.

Bencivenga, V. R., \& Smith, B. D. (1991). Financial Intermediation and Endogenous Growth. Review of Economic Studies, 58, 195-209. http://dx.doi.org/10.2307/2297964

Christopoulos, D. K., \& Tsionas, E. Q. (2004). Financial Development and Economic Growth: Evidence from Panel Unit Root and Cointegration Tests. Journal of Development Economics, 73, 55-74. http://dx.doi.org/10.1016/j.jdeveco.2003.03.002

Cao, T. Q., \& Wang, X. H. (2006). Financial Development and Economic Growth: Empirical Analysis Based on The City of Shandong province. Shandong Social Sciences, 100-105.

Cai, Z. X. (2005). The Research on the Problem of China's Financial Structure Optimization. Doctoral Dissertation of Nanjing Agricultural University.

Fu, Y. S. (2010). Watch The Financial Industry Adjustment of Shanghai from The Financial Ecosystem. Shanghai Finance, 9, 9-12.

Greenwood, J., \& Jovanovic, B. (1990). Financial Development, Growth and Distribution of Income. Journal of Political Economy, 98, 1076-1107. http://dx.doi.org/10.1086/261720

Greenwood, J., Sanchez, J., \& Wang, C. (2010). Financing Development: The Role of Information Costs. American Economic Review, 100, 1975-1891. http://dx.doi.org/10.2139/ssrn.996263

Gurley, J. G., \& Shaw, E. S. (1960). Money in a Theory and Finance. Washington: Brookings Institution.

Goldsmith, W. R. (1969). Financial Structure and Economic Development. Yale University Press.

Guo, Z. Y., \& Zhao, X. K. (2013). Empirical Analysis of Regional Financial Development and Economic Growth-Based on time-series data from 1978 to 2010 of Gansu Province. Economic Survey, 1, 11-15.

Huang, Y. J. (2012). An Empirical Analysis of the Pearl River Delta Economic Growth and Financial Development. Financial and economic, 10, 72-74.

Han, X. W. (2012). Research on Financial of Support Peninsula Blue Economic Zone in Shandong Province-Based on the Empirical Analysis of Shandong Peninsula Six Cities Panel Data. Research on Financial Development, 3, 40-43.

Jia, Z. P., \&Wang, J. (2012). The Path Selection of Financial support Peninsula Blue Economic Zone. China Rural Finance, 23, 49-50.

Li, J. Y., \& Zhang, X. L. (2001). Institutional Arrangement and Reform Conception of Chinese Commercial Banks. Financial Forum, 9.

Lin, Z. Q., \& Yan, J. (2011). Research on the Construction of Banking Support the Shandong Peninsula Blue Economic Zone. Research on Financial Development, 9, 74-79.

Masten, A. B., Coricelli, F., \& Masten, I. (2008). Non-linear Growth Effects of Financial Development: Does Financial Integration Matter? Journal of International Money and Finance, 27(2), 295-313. http://dx.doi.org/10.1016/j.jimonfin.2007.12.009

Macroeconomic Research Institute Task Group of Shandong Province Development and Reform. (2012). The Suggestions of Financial Innovation Support The Blue Economic Zone Building. Shandong Economic Strategy Research, 5, 25-31.

Porter, M. (1990). The Competitive Advantage of Nations. New York: Free press, 261-270.

Qian, M.F. \&Sun, K. (2008).Empirical Research on Regional Financial Development and Economic Development-A Case of Zhejiang Province. Shanghai Finance, 6, 69-72. [Online] Available:http://www.cnki.com.cn/Article/CJFDTOTAL-SHJR200806015.htm

Qin, S. (2009). Financial Industry Cluster Formation and Evolution Mechanism and the Construction of Shanghai International Financial Center. Shanghai Academy of Social Sciences.

Rousseau, P. L., \& Wachtel, P. (2002). Inflation Threshold and the Finance-growth Nexus. Journal of International Money and Finance, 212-240. http://dx.doi.org/10.1016/S0261-5606(02)00022-0

Sun, T. Q. (2002). Research on Financial Organizational Structure. Beijing: China Social Sciences Press. 
Wu, Z. (2010). Financial development and economic growth: analysis from the China experience. Financial Research, 5, 58-68.

Wang, D. X., \& Xu, R. H. (2013). Empirical Study of Financial Development on Economic Growth in Shandong Province. Fiscal and Financial Research, 1, 86-91.

Wang, C. R., \& Cui, Y. S. (2010). Panel Data Analysis on the Relationship of Bohai Financial Development and Economic Growth. Journal of Regional Financial Research, 11, 4-10.

Wang, B. Y., \& Feng, Y. (2010). Financial Support and the Construction of Shandong Peninsula Blue Economic Zone. Shandong Social Sciences, 7, 101-103.

Xiao, H. (2011). The Research of Songzi Financial Layout Optimization Based on The Analysis of Spatial Accessibility (Doctoral dissertation). Wuhan: Huazhong Normal University.

Ye, Y. M., \& Wang, S. (2007). An Empirical Analysis of Financial Development of the Yangtze River Delta on economic growth promoting effects - based on dynamic econometrics analysis applications. Economic Issues, 4, 128-133.

Zhou, L. (2004). Regional Financial Development and Economic Growth in China: 1978-2000. Beijing: Tsinghua University Press.

Zhi, Y. (2013). Empirical Study of Financial Development and Economic Growth in the Yangtze River Delta Financial Development and Economic Growth. Nanjing University.

Zhang, L. L. (2011). Reflections on Scientific Planning the China's Financial Industry Space Layout. Economic Issues, 2, 166-169.

Zhang, Z. Y., Dong, Y. L., He, Y., Chen, X. H., Yang, L., \& Zhang, X. D. (2013). Shandong Peninsula Blue Economic Zone of The financial industry: Present Situation, Problems and Solutions. Economics and Management Review, 1, 151-160.

\section{Copyrights}

Copyright for this article is retained by the author(s), with first publication rights granted to the journal.

This is an open-access article distributed under the terms and conditions of the Creative Commons Attribution license (http://creativecommons.org/licenses/by/3.0/). 